\title{
New Institutional Economics (NIE) Origins of Neoliberalism
}

\author{
Ilkben Akansel \\ Artvin Coruh University, Artvin, Turkey
}

\begin{abstract}
New institutional economics (NIE) which does not pursue the aim and claim of sustaining the institutional tradition is interdisciplinary. It embodies traces of many sciences, such as law, economics, politics, sociology, etc. Being interdisciplinary not only does present various perspectives to NIE, but also makes it quite familiar to the mainstream economics (neoliberal economics). It makes NIE familiar to neoclassical economics, since it accepts the hypotheses, such as methodological individualism, market mechanism, etc. At the same time, it differs from the neoclassical essence, since it has put forward different points of view by adding bounded rationality, transaction costs, etc. Concepts into the literature of economics. As known, neoliberalism aims to eliminate any kind of barrier in front of the economies based on free market logic. However, neoliberalism is not only a stream aiming economic integration, but also a process having political, sociological, and class dimensions. The economic origins of neoliberalism should be searched in the mainstream economics. The economic streams, such as monetarism and supply-side economics, constitute the origins of neoliberal policies. This study aims to examine the correlation of NIE-which takes its economic origins from mainstream economics but improves by adding great differences to them - with neoliberalism. The new perspectives of neoliberalism developed by NEI, such as "bounded rationality", "transaction costs", and "property rights" will be discussed. Consequently, the correlation of neoliberalism concept — which has faced with serious criticisms especially in recent years— with NIE will be put forward; and the positive/negative aspects in these criticisms will be tried to present.
\end{abstract}

Keywords: neoliberalism, new institutional economics (NIE), free market, economic imperialism, political economic, political economy

\section{Introduction}

Neoliberalism is surrounded by paradigms in everywhere and with everything. It seems not possible to escape or hide from it. The long developing history of capitalism conveys all world to "neoliberalism" inevitable. Is neoliberalism truly an inevitable fact or does it want to be like that? Has neoliberalism gained a new dimension adding "neo" adjective?

It cannot be given a definite description of neoliberalism. As every notion cannot be described definitly, neoliberalism may be affected by many facts and may affect many facts in return. Broadening from economics, to culture, the way of thinking, the way of life, etc. Neoliberalism notion is affected mostly by economics and affects economics. Looking at the historical origins of neoliberalism, one can better examine by nesting it with economics.

Ilkben Akansel, Ph.D., assistant professor, Hopa Faculty of Economics and Administrative Sciences, Artvin Coruh University, Artvin, Turkey.

Correspondence concerning this article should be addressed to Ilkben Akansel, Hopa Faculty of Economics and Administrative Sciences, Artvin Coruh University (ACU HOPA IIBF), Sundura mah. Lise cad. No. 79, 08600 Hopa, Artvin, Turkey. 
The epistemological origin of "liberal" word has been derived from "liber" in Latin which means "independent". After many changes over time, "libéral" notion has turned a political discourse in France at the 18th century. According to Eres (2008, p. 757), "liberalism can be described the most generally advocating individual freedom and emphasizing it mustn't be depend on any upper spine and except her/his rational mind". The early libearal philosophers like Rousseau and Hobbes have wanted to draw the borders of freedom in order to provide the security of society. Depriving ideologs of the question of the borders or the price of freedom, it has been curcited by market which is the most spritless machine handling untouched created by men until today.

There is such a no dependence, debt, blood ties, love, hate, or least expectation of market to someone. The market tries to regulate production and distrubution problem with price mechanism which has no sector could be solved by some of the institutional arrangements like political, social, religious, and familial before its absolute dependence. (Eres, 2008, p. 757)

While doing this, it must be accurately put in order to "benefit principle" one of which is a moral basis of liberalism. The market forges the choices of people individually like a computer, then it will supply society's choices ordering an output. After the World War II, unsocialist wing of anti-facist encamp has accomplished to rebuild capitalist production which has never been given up by market doctrine till today. Founding the ways of protection of capital, how to self-protect the market mechanism is the best achievement of Keynes.

The concept of neoliberalism as economics politics can be summarized economic liberazation, removing price controlling, minimizing the state, and restricting state interventions, privatizing public enterprices, obtaining fiscal dicipline, reducing public payments, closing budget deficits, and narrowing money supply (deflation politics). It will be understood that all these politics mean to release the market which is chained as a drogon. (Eres, 2008, pp. 761-762)

In that case, the history of neoliberalism proceeds simultaneously with the history of economics in the 20th century. As it is known, World War II was a revolutionaire incident in many fields like economics, politics, cultural, etc. After such a huge destruction witnessed by all the world, revitalizing the economics has been dished the great economist Keynes's opinions up. Within 1970's when capital class wanted to reobtain its old glorious days, Keynesian economics has its throne snatched to monetarism, supply-side economics theories, etc. Especially, in the 1980s all over the world, such theories have become a blood brothers with these theories with the rules of Thatcher, Reagon, makes neoliberalism transformation.

Liberalism is set over by the basis of individual freedom; neoliberalism is scrolled by one step further to freedom of the market. This rough process has been brought serious restrictions in receiving shares of huge mass from the revenue. Thereby, within the 1990s, this rough crust of neoliberalism's economics dimension must be striped. Within the 1990, an old friend retook a stage chaning its identity: new institutional economics (NIE). NIE has solved from old institutional economics (OIE), but in many points, it is a theory which rejects many assumptions of OIE. Actually, the only common feature which NIE and OIE share is the notion of "institution". Except this, it can be seen that NIE has many assumpions sharing with neoclassical economics. As it is known, neoclassical economics and many theories which were derived from it are the hard core of neoliberalism.

This study aims to investigate the relationship among NIE which has many similar thoughts shared with neoclassical economics but at the same time generates several new ideas and neoliberalism. NIE gives 
significant help with the notions "bounded rationality", "transaction costs", and "property rigths". These three notions are particulary important while definding market mechanism by the mediation of neoliberalism. There are many exercises which examine the relationship between NIE and neoliberalism, so this exercise is a very unique one. Exclusively, examining this relationship by the mediation of transaction costs and bounded rationality will give a chance to understand why neoliberalism needs market mechanism so much.

This paper will be divided into three parts: Firstly, introduction section is the first part of it; secondly, the study will try to seperate relationship between NIE and OIE, and analyze why NIE has a deep relationship with neoliberalim, while doing this, some important concepts will enlighten the minds: bounded rationality, transaction costs, and property rights; lastly, the study will summarize the relations of all.

\section{Literature Review}

\section{The Relation Between NIE-Neoliberalism}

Neoliberalism gets to affect the lives each day. However, this effect is somehow in a good way or a bad way, is it debatable? Neoliberalism has not been descent from the sky. In the long capitalism period, it has improved itself year by year. Many economics theories gave a support to it, few did not. Although, it can be said that many important economics theories, which are supported by significant economics institutions like WTO, IMF, etc., believe in neoliberalism. So, one can claim that many mainstream economics theories, which are arised from neoclassical economics hard core, are related to neoliberalism.

Some of the theories have been even created to renew neoliberalism. One of these theories is NIE. Although, NIE has been taken to the stage by OIE, it has very few notions to be taken as common. Neverheless, NIE can be said a very good supporter for neoliberalism.

Thereby, one can always remember that OIE and NIE are stuffy half sisters. Before NIE was born, her elder sister OIE has arised early in the 20th century in USA.

\footnotetext{
The old institutional economics rejected classical economic theory, the theory of Adam Smith; the new institutional economics, in some versions anyway, rejects or at least severely questions neoclassical economic theory, as expounded for example by Paul Samuelson. The reasons for this rejection are both methodological and political. In order to facilitate mathematical formulation and exposition, neoclassical economic theory routinely adopts what appears to be, and often are, from both a physical and a psychological standpoint, highly unrealistic assumptions: That individuals and firms are rational maximizers, that informationis costless, that demand curves facing firms are infinitely elastic, that inputs and outputs are infinitely divisible, that cost and revenue schedules are mathematically regular, and so forth. (Posner, 1993, p. 74)
}

The origin of OIE is the United States. While Marx represents the economic stream opposing to the mainstream economy in Europe, OIE has undertaken this representation in the United States at the beginning of 20th century. Methodological and political opposition makes harmonization of OIE with neoliberalism impossible. For this reason, new version of the OIE stands closer with NIE neoliberalism in terms of both methodological and political aspects. Standing OIE away from being mathematical leads to more realistic consideration of the response for questions on economic events of class distribution, i.e., who takes what shares and how these shares are distributed. Physical and psychological opposition finds its compensation generally in "homo economicus" concept. Assumptions that individuals and companies will maximize their benefits and profits do not find any compensation, becoming of the demand curved, the infinite divisibility of inputs and outputs due to operating them rather in favour of companies in the market in the real economic life. OIE does 
not find these assumptions realistic, so it was not possible to allow requests of neoliberalism.

The adjective "new" impliest that there was a previous institutional economics, and of course there was, and in fact still is. The best known of the original institutionalists, Thorstein Veblen and John R. Commons, flourished in the early decades of this century. (Posner, 1993, pp. 74-75)

Influenced by the broader revival of interest in institutions in economics, represented by the rise of new institutional economics in the 1980s, institutions started gaining popularity by the early 1990s as an explanation of international differences in economic development, even in places, such as the World Bank and the InternationalMonetary Fund (IMF), which had been rather hostile to the notion. (Stein, 2008, pp. 38-42)

However, it is from the late 1990s that institutions have moved to the centre stage in the debate on economic development... In accordance, the IMF and the World Bank started to impose many "governancerelated conditionalities", which required that the borrowing country adopts "better" institutions that improve "governance". (Chang, 2011, p. 1)

In other words, the countries should not have institutions as the former times, instead, an institutional is that the governance would rule must be taken into consideration. These institutions should also be established in a structure that paves the way to neoliberal policies. NIE from the economical aspect is in an appearance of a current furnishing the "governance" institutions required by the neoliberalism.

The main different argument between liberalism and neoliberalism is on the role of the state. Liberalism says that state must play a role of "night-watch state" like big-brother. He must protect his private sector, but must not interfere with private sector's business. On the contrary, neoliberalism wants the state not to both interfere with its business whilst being helped by every kind of economics support for its business.

Classical liberalism is often associated with the belief that the state ought to be minimal, which means that practically everything except armed forces, law enforcement and other "non-excludable goods" ought to be left to the free dealings of its citizens, and the organisations they freely choose to establish and take part in. This kind of state is sometimes described as a "night-watchman state", as the sole purpose of the minimal state is to uphold the most fundamental aspects of public order... Modern liberalism is, on the other hand, characterised by a greater willingness to let the state become an active participant in the economy. This has often issued in a pronounced tendency to regulate the marketplace, and to have the state supply essential goods and services to everyone. Modern liberalism is therefore, for all intents and purposes, a profound revision of liberalism, especially of the economic policies traditionally associated with it... Such "modern" views could be associated with 19th-century theorists, such as Benjamin Constant and John Stuart Mill. More recently, John Dewey, William Beveridge, and John Rawls have articulated similar ideas... Keynesianism, as it came to be called, was the dominant theoretical framework in economics and economic policy-making in the period between 1945 and 1970, but was then replaced by a more "monetarist" approach inspired by the theories and research of Milton Friedman. (Thorsen Einar \& Lie, 2007, p. 8)

Since then, we are led to believe that "neoliberalism", i.e., monetarism and related theories, has dominated macroeconomic policy-making, as indicated by the tendency towards less severe state regulations on the economy, and greater emphasis on stability in economic policy rather than "Keynesian" goals, such as full employment and the alleviation of abject poverty. (Thorsen Einar \& Lie, 2007, pp. 4-8)

The preponderance of Keynesian policies during the years of Liberalism rule was a natural and logical result of the conjuncture. Because in the course of a conjuncture after World War II where all the economies were collapsed and increase of demand had not been possible at all cost, defending underemployment equilibrium instead of full employment equilibrium was the most logical conclusion. However, production growth in the economy had begun to distribute the increasing rate of profit to working class in a much more manner. While this was a tolerable situation up to a point, especially within 1970s, the capitalist class started to show teeth more than earlier. As mentioned at the beginning, the basis of neoliberalism is regarding to whom and how production factors will be distributed. The capitalist class who desires to take a bigger slice of the pie 
and economical backers of these, the monetarist and successor theories predicted a state model with less intervention to the economy instead of making any kind of regulations to pave the way for the capital. Just after that point, Keynesian models were discredited. However, the sharp opinions of monetarism and other successor theories had to be smoothed and softened slightly. Just at this point, specifically during 1990s, NIE began to take its place in the scene of neoliberalism.

So, economics is based on market mechanism. Market mechanism is very important for capitalist economics. Because, the system called that neoliberalism is based upon the capitalist system. The essence of capitalist system is production. Economic approach is determined basically with the presumption to which means of production belong. The problem in the proprietorship of means of production begins with the basic distinction in the answers given to questions for whom and by whom the production will be done. Socialist approach predicts that the means of production be in the hands of public sector. It means that the private sector will not be efficient in taking place in the economy; public sector would determine the production and prices. The capitalist system foresees the production made by the hands of private sector. For proprietorship of means of production being in the hand of private sector, the prices and amount of production are determined by the market system (Eğilmez, 2015).

Supporting private sector does not go through well for all the time. Market balance can be deteriorated by some reasons. Although, the real situation does not go well, everything is fine in a fictious world on the paper.

\footnotetext{
Mainstream economics, as one sees it in the journals and the textbooks and in the courses taught in economics departments has become more and more abstract over time, and although it purports otherwise, it is in fact little concerned with what happens in the real world. (Coase, 1998, p. 73)
}

This situation reflects itself in the education too, for example, "American and European opinions also systematically deviate with respect to the distinction between micro and macro, ..." (Frey \& Eichenberger, 1992, p. 219). Why is this important? Because changing the point of view in education is determined by change in literature. However, sometimes some notions do not change, in one way will they start to use different kinds of meaning. When meanings are changed, the point of view in the economics world can be totally changed.

The concepts of liberalism and neoliberalism are connotations bearing meanings absolutely different from each other. The most significant distinction among them is while liberalism accepts individual freedom as a prerequisite, neoliberalism converts this paradigm to superiority of the market (Eres, 2008, p. 763). Both liberalism and neoliberalism, price system (= price mechanism) is the key factor in order to solve the market problems. If man once had understood this system, there would not be any problem to solve.

The price system is just one of those formations which man has learned to use (though he still very far from having learned to make the best use of it) after he had stumbled upon it without understanding it. (Hayek, 1945, p. 528)

Hayek actually had a good deal of sympathy for many features of what is conventionally labelled as the welfare state... Hayek's quarrel with socialist movements was therefore not primarily with their ends, as it was with the methods they historically put forth to achieve them, namely central planning of economic distribution and production... Hayek proceeded to argue that these must limit the ambitions of government. No central authority, however well informed, is capable of grasping the totality of the social situation. Incomplete information, wrong interpretation, and the incapacity to anticipate all possible outcomes make faith in central planning misplaced. Further, Hayek observed that the ambition of social reformers who would drastically remake the world from the top-down is also necessarily restricted, since their ideas are, like anyone else's, products of the world in which they are a part. As a result, Hayek argued that radical social change is never the result of deliberate construction but happens over time through the gradual accretion of unforeseen and unintended human actions. (Bholat, 2010, pp. 178-179) 
So the first question must be asked is what is neoliberalism. This question is hard to answer. Because, there are too many descriptions of neoliberalism. At the same time, some of the great economists' perceptions have been a starting point of neoliberalism. In the development of neoliberalist thought, there have been some frontiers and philosophers, such as Joseph Alois Schumpeter. Because, at the early beginnings of the 20th century, Schumpeter is one of the most powerful delegates of capitalism with his thoughts about "entrepreneurship" and the issues which he has handled. Despite the fact that he sometimes worried about a possible downfall of capitalism, he desires to create a new system which can be determined by the continuity of capitalism, as if it would never be gone off. Thereby the first step sounds of neoliberalism which can be realized of his desire have been motivated.

At the end of 1940's, neoliberal manager Joseph Schumpeter has caused to make a serious shock to American Economic Association calling economic development as a (irrepressible) walk to "socialism"... Milton Friedman has gathered a cadre which has become really a frontier power until 1970's in order to educate and who are of the youngest students of Schumpeter meaning of a u-turn to a road to socialist serfs. Those cadres have led to people to have freedom again which the sprit of evaluate of freedom innovator soul, property rights, and the world of profit. (Schmidt, 2008, pp. 66-67)

So, neoliberalist era has come to stage after a wide range of economical, historical, etc., changes. But no other circumstance gave a powerful effect to neoliberalism rather than the World War II. Because, after the war, Keynes's thoughts became a "dux maximus" in the economics history. Besides, its fall was very keen.

Neoliberalism emerged as an ideological response to the crisis of the "Keynesiam welfare state", which was precipitated by the generalised capitalist crisis associated with the end of postwar reconstruction boom and was brought to head by the escalating cost of the US war against Vietnam at the beginning of 1970s. (Clarke, 2004, p. 58)

But, before neo-Keynesianism has ruled on the neoliberal era, neoliberalism must have cruised on its own course. Although, liberalism and neoliberalism carry different positions from each other, liberalism is neoliberalism's "grandfather". “... the neoliberal ideal of the 'self-regulating market' as the main engine powering the individual's rational pursuit of wealth had been a core tenet of economists since the late 18th century" (Steger \& Roy, 2010, p. 2).

The liberal doctrines propounded by Adam Smith came under attack from two directions. On one hand, Smith's ideal society was one of isolated individuals each pursuing his own self-interest (while women and children remained dependants within the family) — as Margaret Thatcher notoriously proclaimed. (Clarke, 2004, pp. 50-51)

Finally, the point must be stressed that most of the restrictions discussed here are those imposed by the state. To argue for a change in the content of the right of ownership, therefore, is to argue for a change in the allocation of resources to which legal support is given. (Furubotn \& Pejovich, 1972, p. 1140)

Neoliberalism dominates modern globalisation. Its practice is justified by a set of theoretical claims rooted in standard economics theory. Markets are represented as optimal and self-regulating social structures. It is claimed that if markets were allowed to function without restraint, they would optimally serve all economic needs, efficiently utilise all economic resources and automatically generate full employment for all persons who truly wish to work. (Shaikh, 2004, p. 41)

Given all these effects, neoliberalism has considerably evolved over time, solely assuming that the state should not intervene to the economics and private sector should single-handedly undertake all economical processes. Actually, the sprit of "entrepreneurship" which led to modernize capitalism has submitted a key concept pioneering of thoughts of Schumpeter. Truly, capitalism, when looking at unique thought developed by Schumpeter on "entrepreneurship", is the silver bullet (magic wand) which makes the private property's profit 
rear up. Supply-side economics, monetarism, etc., economics theories showing continuation of neoliberalism have built up of all this systematic of thought. However, the last crisis causing neoliberalism drew neo-Keynesian thought. The assumption mostly given importance by the neoliberalism is the independence of economy and other institutions. Despite the height of emphasis of liberalism, liberal practices and associated institutions are seen to differ from country to country and from culture to culture.

Neoliberalism is different from 19th century's liberalism, a more conservative concept and the product of 1980s.

... Contemporary neoliberalism, which emphasis the efficiency of market competition, the role of individuals in determining economic outcomes, and distortions associated with government intervention and regulation of markets, is principally with Chicago School of Economics. Two critical tenets of neoliberalism are its theories of (1) income distribution and (2) aggregate employment determination. With regard to income distribution, neoliberalism asserts that factors of production (labour and capital) get paid what they are worth. This is accomplished through the supply and demand process, whereby payment depends on a factor's relative scarcity (supply) and its productivity (which affects demand). With regard to aggregate employment determination, neoliberalism asserts that free markets will not let valuable factors of production (including labour) go to waste. Instead, prices will adjust to ensure that demand is forthcoming and all factors are employed. This assertion is foundation of Chicago School monetarism, which claims that economies automatically self-adjust to full employment, so that use of monetary and fiscal policy to permanently raise employment merely generates inflation. (Palley, 2004, p. 20)

What is required to understand when market worshipping of neoliberalism is talked about is a situation related to income distribution. As it is already known, the two elements of production are labour and capital. Matching these two in a form to balance with each other shall ensure equilibrium in the labour market. This balance works through the labour price. When the labour price is in balance, neither labour nor capital will be unemployed, no factor will be wasted. Thanks to stability mechanism created by the price, the economy will be automatically self-adjusted and no unemployment will remain. Shortly, the psychological world of the neoliberalism is at somewhat an Alice in Wonderland. Imbalances that hinder the progress of economy are "each a bad witch" and automatic adjustments are "magic elixirs" able to beat them and reorganize the economy.

In the author's opinion, the relation of neoliberalism with NIE is becoming more visible at this point. According to OIE, every economic application is an "institution" in fact, although NIE does not share this opinion, it is able to establish its correlation with neoliberalism over the following institutions: All of the significance of trade unions, law governing minimum wages, employee rights at work, and system of social protection are institutional applications. NIE includes property rights, transaction costs, and so on concepts into institutional applications for the purpose of more comfortable realization of all these and even more.

... despite the decline of official Keynesianism, the fiscal and monetary techniques used by governments throughout the neoliberal era have retained a Keynesian character... The new intervention draws on the second major development within mainstream economics, namely the gradual incorporation of information, institutions, and social customs into microeconomic analysis. This has offered fresh scope for economic analysis of the occasional, or even systematic, failure of free markets to deliver optimal results. Mainstream economics now increasingly accept free markets might malfunction due to a number of reasons, including asymmetry of information among market participants, poorly performing social institutions, or even lack of trust across society... Nevertheless, the new economic interventionism does not challenge the core of neoliberalism. (Lapavitsas, 2004, pp. 30-31)

The first is to be accepted by neoliberalism that asymmetric information in the market disrupts the market 
balance. This means that while the market concentrates on the company unilaterally, it disregards the demand side. So the company maximization is the first priority. Neoliberalism in practice means the Washington consensus as a practical development strategy whose advocates can, with some justification, distance themselves from the particular neoliberal theories developed by the so-called Austrian school launched by Hayek (Munck, 2004, p. 60).

It is true that the two categories of phenomena, globalisation and neoliberalism, are related; but they refer to distinct sets of mechanism. Globalisation or the internalisation of the world economy is an old process, one that Marx identified in the middle of the 19th century, in the Communist Manifesto, as an inner tendency of capitalism (the establishment of a world market). (Duménil \& Lévy, 2004, pp. 9-10)

In a broad historical term, what this new form of imperialism amounts to is nothing less than the extensive "re-embedding" of capitalism across the world, as a social order that is at once global and national (Radice, 2004, pp. 97-98). Secondly, as the priority is given to the interest of one side only, the balance on the other side has been disturbed. Of course this case does not create a micro but a macro impact. The duty to reinstate such disturbed balances has been fulfilled by applying to suggestions of an old friend (Keynesianism). One of the main reasons the fall of OIE like Keynesian economics from grace is that individual decisions are being based on psychology rather than rationality. This is a feature shared by Keynes and OIE. Reasons of psychological features are for describing rational acting motivation of the people. When you disregard psychology, the human becomes a robot created technologically. On the contrary, when psychological actions are taken into consideration, individuals may not be able to realize any consumption patterns desired by the neoliberalism.

While neoliberalism has been affected by many political streams as economic programs, the impact of NIE that started in 1990s may be assessed from several perspectives. While the first is related to the macro economical dimension, the second is related to macroeconomic dimensions. As property rights are effective in macroeconomic dimension, transaction costs are more effective in micro dimension.

Three aspects of modern neoclassical theory are especially important in explaining the policies associated with neoliberalism and the Washington consensus. At the microeconomic level, neoclassical theory presumes that the market is efficient and the sytage is inefficient... At the macroeconomic level, this approach presumes that the world economy is characterised by capital mobility and the relentless advance of "globalisation". (Saad-Filho, 2004, p. 113)

By this way, neoliberal economics action avoids its problems in terms of supply side.

The problem of the nature of the firm is at the origin of the research program of new institutional economics (NIE). The problem was first addressed by Coase (1937), who explored the reasons why authority and direction are economically superior to market relations. (Palermo, 2000, p. 573)

Shortly, NIE has a great impact on neoliberalism. Also, NIE is affected by neoliberal economics implementations. Both are affecting each other with their spirits of "free maket" ideology. Especially, NIE's notions "bounded rationality", "transaction costs", and "property rights" give a chance to behave to neoliberalism, as if it has not any destructive economical conclusions.

\section{Triple Siblings: "Property Rights", “Transaction Costs", and "Bounded Rationality"}

With lighting all of these if one can remember that NIE criticizes neoliberalism by the mediation of rational mind information, "bounded rationality" is an alternative. It will be discussed below. The significance of roles undertaken by companies in the market through transaction costs is also very important for 
neoliberalism. As it is known, neoliberalism brings the market concept in the foreground. It is a concept that determines everything in the market and is worth worshipping. It is essential to remove all the obstacles that may occur, for the proper functioning of the market. Here the concept of transaction costs gains significance at this point.

As a theoretical reference, the system of pure markets is defined in a context of zero transaction costs. In such an ideal context, as is well known, there can be market failures. The analysis of such failures, however, is not developed by Williamson. Instead, the definition of a zero transaction costs context has only a negative role in the construction of Williamson's framework: Its definition serves uniquely as reference to define context of positive transaction costs. Williamson thus focused only on those failures caused by transaction costs, leaving apart other kinds of market failures. [Williamson, 1975, p. 20]. The "market and hierarchies" framework is built on three theoretical categories: (1) opportunism, (2) bounded rationality, and (3) asset specificity... Market failures, under given conditions, can be reduced by means of hierarchical organizations (such as firms). (Palermo, 2000, pp. 576-577)

Coase described firms and markets as alternative means for doing the very same thing. The allocation of activity as between markets and hierarchies was no longer taken as given, but needed to be derived. Should a firm make or buy? Which transactions go where and why? The firm was reconceptualized for these purposes as a governance structure (which is an organizational construction). (Williamson, 1998a, p. 75)

Then its connection with NIE may be installed through the market and company's mechanism. To the extent that the company reduces costs of doing business in the market will be much more articulated into the market and after a while, the company and the market will start to be mentioned as synonyms.

However, on the contrary to the prediction of effective use of resources by the neoliberalism, while the company, which is a party of the market, gains efficiency; consumers efficiencies, which is the other party, will start as a problematic.

During recent years, the term "institutional economics" has been applied to an ever-increasing variety of economic approaches or schools of thought. Most people recognize the terms "institutional economics" or "American institutional economics" or "old institutional economics" (sometimes now "original institutional economics") as applying to the tradition of economics associated with Thorstein Veblen, John R. Commons, Wesley Mitchell, and Clarence Ayres... But in recent years, the term "new institutional economics" has become well-established as referring to the tradition to of work stemming primilary from the transaction cost approach of Ronald Coase, Oliver Williamson, and Douglas North. (Rutherford, 2001, p. 173)

In this point, it is possible to say that the OIE represented by Veblen is much closer to liberalism. Because as it is already known, the most important intellectual origin of liberalism is individualism. The man who considers its interest and is able to take rational decisions for this sake is able to drag institutions where he wants. Thus institutions also exhibit some kinds of human behaviour.

At the micro level, he developed his concept of the "transaction" as the basic unit of analysis. In turn, the terms of transactions were determined by the structure of "working rules", including legal rights, duties, liberties, and exposures, and by economic (bargaining) power. (Rutherford, 2001, p. 176)

The idea that individual tastes are not given, but shaped by institutional circumtances and by particular influences such as advertising, is a major theme in the writings of Galbraith. [...] Galbraith ... insisted that individual "wants can be synthesized by advertising, catalysed by salesmanship, and shaped by the discreet manipulations of the persuaders..." His analysis puts particular emphasis on the effects of advertising on individual wants. This is one version of the core institutionalist story. (Hodgson, 2000, p. 325)

This point reveals it in the concept of "homo economicus". Human typology who is selfish does not care about anything other than his interests and is the basis of neoclassical economy that generally reflects economic 
thinking structure of neoliberalism. Neoliberalism founded on this foundation seems to keep individual interest equal to the market interest. The situation called as the market interest is not really anything other than the interests of the capitalist class. Neoliberalism is, as previously mentioned above, indeed an economic program that promotes the interests of the upper class by transferring tax revenues to the pockets of capitalist class again. Yet NIE is alleged to be closer to the mainstream economics. OIE has a structure putting human being at the centre of the "institution" being mutually interactive and nested with institutions. "... NIE—particularly that of the more neoclassical core is by no means identical with the benchmark for ...the programme of institutional (as distinguished from psychologistic) individualism ..." (Langlois, 1989, p. 292).

To break away from this structure and get closer to "homo economicus" has transformed NIE to a nested position with the market. The concept the author's calls as market as a conclusion meets the supply and demand at a point called "price". The man's problem that lies here and at the foundations of neoliberalism is the desire to create a demand not backed by the real income. Indeed a pumped demand destabilizes the economy.

... the institutional economics focuses on the study of the structure and functioning of an evolving system of human or cultural restrictions and includes explicitly in addition to individual behavior and individual wants, the consideration of group behavior, and public aims. (Kapp, 1968, p. 2)

Although NIE does not exactly have the evolutionary feature inherited from OIE, since inter-disciplinary transitivity is high, it may more comfortably focus on human behaviours.

While the Robbinsian definition in effect enthrones homo economicus institutional economics replaces the concept of the economic man by something which we may call the "institutional man". Both these concepts are, of course, abstractions ... but wheras the former is constructed by isolating and accentuating one conceivable aspect of human behavior, the latter is derived from observation of concrete behavior patterns and leaves room for the consideration of different forms of behavior in different societies. (Kapp, 1968, p. 2)

However, the problem of rationality could not be fully overcome yet. The prediction that each individual would choose the most economical option for him in a rationalistic manner takes place within NIE, but not as much as in neoclassical economics. Yet this is a breakup from the "institutional human" logic that does not agree OIE's human behaviours as evolutionist and the same in anywhere and any conditions. This breakup is striking (dramatic) from the view of NIE's relationship with neoliberalism. Because the rise of neoliberalism and rise of NIE are almost at the same period of time.

However, institutional economics does not presume that its habit-based conception of human agency itself provides enough to move toward operational theory or analysis. Additional elements are required. In particular, an institutionalist would stress the need to show how specific groups of common habits are embedded in, and reinforced by, specific social institutions. In this manner, institutionalism moves from the abstract to the concrete. Instead of standard theoretical models of given, rational individuals, institutionalism builds upon psychological, anthropological, sociological, and other research into how people behave. Indeed, if institutionalism had a general theory, it would be a general theory indicating how to develop specific and varied analyses of specific phenomena. (Hodgson, 1998, p. 169)

Agreements like North American Free Trade Agreement (NAFTA) and World Trade Agreement has increased transnational power and profits at the expense of destabilization of the economy and deterioration of working conditions and quality of life... so very many working employees accept these as true and incontestable truths. (Hart-Landsberg, 2008, p. 79)

Additionally, many scholars pointed that neoliberalism theory has criticized that it is exposed to a serious criticism in ideological: 
State did not draw back after neoliberalism took the play of Keynesianism. But, neoliberal ideology has veiled this intervention with globalisation and adapting new economics discourses. Today where tax revenues are clearly transferred again to pockets of landlord classes, the new liberal state has been unmasked. (Schmidt, 2008, pp. 69-70)

The new institutional economists, however, are not against economic theory tout court. This is the vital difference between them and old institutionalists... Rejection of formalism, or of a certain version of that formalism, is the negative side of the new institutional economics. The posite side is the study of institutions. Yet it may be diffucult at first to see how an interest in institutions could distinguish the new institutional economics from all but the most abstruse mathematical economics. (Posner, 1993, pp. 75-76)

The connection established by NIE with neoliberalism is directly related with NIE's assumptions. The author may list these assumptions generally as "methodological individualism", "bounded rationality", and "transaction costs". The first two of these belong to the nature of economic individual; the third is related to functioning of market mechanisms (Şenalp, 2007, p. 61).

For this reason, the new economic program to respond neoliberal logic is NIE. Perhaps the most powerful aspect of NIE is the promise of giving opportunity to neoliberalism to get rid of being mathematical. As mentioned earlier above, OIE has three main theoreticians: Veblen, Mitchell, and Commons. Of course, the father of OIE is Veblen indeed Common's contribution especially to OIE, have offered very significant contributions in explanation of human behaviours.

... Commons' contribution to institutional economics to institutional economics ... should be given credit for attempting to provide institutional economics with the systematic theory that was not bequeathed by Veblen, Mitchell, or any other American institutionalist. ... A successful development of a Veblenian approach was made much more difficult by the shift in prevailing academic opinion away from instinct-habit psychology and Darwinian modes of thinking. In addition, the rise of positivism and behaviourism created adverse conditions for the development of institutionalism along Veblenian lines. Commons' response to these circumtances was an abandonment of instinct-habit psychology and admission of some aspects of behaviourism. (Hodgson, 2003, p. 569)

Consequently the "institutional man" approach that puts the man at the centre of the nature and institutions and tries to assess human behaviours in an evolutionist regard rather than the smart man who pursuits solely in his interest (homo economicus) as claimed by neoclassical economics has been possible by Common's contributions. He succeeded this contribution without any deviation from Veblen's line in this issue but approaching positivist and behaviourism requirements, which oppose to each other.

As compared with other interesting contracting issues — for labor, with consumers, or for capital—contracts among firms in intermediate product markets have the advantage that the two parties can be presumed to be risk-neutral and, roughly, to be dealing with each other on a parity. Each has extensive business experience and has or can hire specialized legal, technical, managerial, and financial expertise. Attention can therefore be focused on the attributes of the transaction and the properties of alternative modes of governance - rather than be deflected by differential risk aversion or by competence disparities among the parties as might arise, for example, with contracts between firms and inexperienced consumers. (Williamson, 1998b, p. 30)

If the author studied the core of transaction costs concept slightly more, these points may be told to come in the forefront: The unilateral role of the company in economy within the concept told as the market has been increased backed by rules of the law based actually on bringing the law, economics, and organization together. This case relates to satisfaction to be felt by the company/companies for operating in higher profit margins in the point where neoliberalism is related to the distribution of production factors. The company offers services to other market powers by being already in the market. Thus, it facilitates governance. In other words, it 
facilitates the role of the state, which is already unwanted to intervene the economy and undertakes economic roles. The role to be undertaken by the state at this point is to offer maximum support to the private sector's production, organization, etc., through any kind of political means including tax and so on. The allegations that NIE did not solely get closer to neoclassical economics but sometimes took its place were expressed by the names inside NIE.

The NIE is based on methodological individualism. It shares this assumption with mainstream economics. This assumption distinguishes it from the old institutionalists. Methodological individualism means that all outcomes must finally be explained by individual action. This, of course, is not to say that all outcomes observable on a social level are the intended result of some individual action expressly trying to bring them about. ... We now turn to two assumptions that differentiate these approaches, namely the assumption of (a) bounded rationality and (b) positive trans- action costs. These assumptions are closely related to each other. Conventionally, it is assumed that individuals try to maximize utility in a perfectly rational way. They can preview every possible state of the world, thus know all the options they can choose from, and are able to evaluate all their possible consequences instantaneously and costlessly. ... Herbert Simon (1955) recognized that the assumption of perfect rationality made little sense in situations of uncertainty and introduced the concept of bounded rationality. He also departed from the notion of utility-maximization and put satisficing in its place. It has been shown that, under conditions of un-certainty, it can be rational to use rules as guidelines on how to behave in certain situations [Heiner, 1983]. (Voigt \& Engerer, 1999, p. 130)

While NIE substitutes neoclassical economics called the mainstream economics, of course it should be agreed to do this under the same assumptions. How has neoliberalism defined it as a new and different from liberalism, the same relation is valid of NIE and neoclassical economics? Although methodological individualism that is principal assumption of neoclassical economics was agreed by NIE as well, the above mentioned bounded rationality and positive transaction costs concepts save human and companies from the unhealthy drive of perfectionism of both neoclassical economics and provides a more comfortable playground for neoliberalism.

Although NIE feels confidence to the market, it is seriously separated from market worshipping of the neoclassical economics. Assumptions of neoclassical economics away from the reality may be listed as follows: (1) Persons and companies are rationalist and act with the stimulus of maximization; (2) the information has no cost; (3) demand curves of companies are endlessly flexible yet inputs and outputs are infinitely divisible; and (4) cost and income indicators show a linear mathematical relation (Şenalp, 2007, p. 64).

One of the most important notions of neoclassical economics is "rationality". Rationality deals with maximization problem. Individuals or firms are chosen for the best rational option to raise their benefit or profit. Thereby, both individual and firm will be satisfied by their decision. Their decision will reflect to the market by the mediation of price mechanism. The market will be in equilibrium. The only problem here is debatable "rational" notion.

NIE tries to point out that the economical institutions are also important just as "companies" and the "state". It makes an analysis from "individuals" toward "institutions" and accepts the "individual" as data. This approach is defined as "methodological individualism". According to which, all economic events may be described by only behaviours and tendencies of the individual. Individualist approach defines individuals as isolated and making choices in pursuit of pleasure and benefit (Arrow, 1994; Şenalp, 2007).

Methodological individualism is an assumption by NIE with established economics. This sharp separation of NIE from OIE has got closer to the language of economics as specified above. The situation desired to be expressed with this term of "language of economics" is the neoclassical economics. The answer of the question why this connection is important may be given by explicating the connection between NIE and neoliberalism. (Şenalp, 2007, pp. 60-62) 
Institutions are the humanly devised constraints that structure human interaction. They are made up of formal constraints (e.g., rules, laws, and constitutions), informal constraints (e.g., norms of behavior, conventions, and self-imposed codes of conduct), and their enforcement characteristics. Together they defined the incentive structure of societies and specifically economies. Institutions and the technology employed determine the transaction and transformation costs that add up to the costs of production. [...] The neoclassical result of efficient markets only obtains when it is costless to transact. (North, 1994, p. 360)

The word "rational" lacks a clear definition; and passing that difficulty, there can be noneconomic theories of rational choice, in which few predictions of ordinary economics may hold, for example, because the theory assumes that people's preferences are unstable. (Posner, 1987, p. 1)

Rationality problem is a controversial concept for many economics theories, so does NIE. However, one can look at the theories to understand which one is controversial for rationality; one will see that those are anti-neoclassical economics. Yet, NIE is one of the most unique theories arising from the very core of neoclassical theory, and then one can criticize this notion. Thereby, NIE finds the solution to solve the rationality problem in "bounded rationality".

Supply sided economics, rational expectations theory, etc. that are economic doctrines set forth at the beginning of the neoliberalism, especially NIE, which started to rise during 1990s, has provided serious contributions to the economical dimension of neoliberalism. With a more clear prospect, NIE is to find answers for what-how-for whom questions in respect of institutional and especially economic applications view.

One of the important issues for NIE is the "property rights" concept. This concept is important in terms of exhibiting the break of NIE from OIE. Because when the OIE has emerged for the first time, OIE was positioned as an economic stream in opposition to mainstream economics. So, the "property rights" concept is not a concept much supported by OIE. Attributing great importance to property rights by NIE is an aspect closing it with the mainstream economics. Therefore, it is possible to say that NIE has a relation with neoliberalism well through property rights concept. The commencement of NIE's rapprochement with property rights is important in this respect.

It can be said that NIE's "property rights" and the orthodox economics' (= neoclassical economics), "property rights" have different points of views. The emphasis on property rights in the orthodox literature is so strong that it has even attracted the criticism that it amounts to "property rights reductionism" (Rodrik, 2004). This over-emphasis on property rights institutions is particularly problematic, when the orthodox theory on the relationship between property rights and economic development suffers from a number of conceptual, theoretical, and empirical weaknesses (Chang, 2006).

The property rights in neoclassical economics are related to liberalism. Because, as it is known, liberalism's main idea bears to Adam Smith's "laissez faire, laissez passer". In here, if one individual has a possession, he has an absolute and undebatable right on it, for example, if a merchant has some fabric, his one true wish from the state is that all the barriers in front of the free trade are to be removed, including high taxes. Because, he saw that taxes are the interferences of owing and selling possessions for free selling. In the neoliberalist era which has an important relation with NIE, property rights are seen different and complexed. The "property rights" literature begins with the presumption that modifications must be made in the conventional analytical framework, if economic models having wider applicability are to be developed (Furubotn \& Pejovich, 1972).

Although rapprochement with neoclassical rapprochement is concerned, property rights of NIE do not go in parallel for the aspect of taking optimization especially issue into consideration in a different form. 
Relative to this argument, the property rights approach can be understood as an attempt to empirically meaningful optimization problems by associating the utility function with the individual decision maker and then introducing specific content into the function. In this way, it becomes possible to consider the behavior of the decision maker within the firm, government bureau, or similar collective agency. The other key the analysis is that different property rights assignments lead to different penalty-reward structures and, hence, decide the choices that are open to decision makers. Instead of treating the firm as the unit of analysis and assuming that the owners' interests are given exclusive attention via the process of profit maximization, the utility maximizing model emphasizes individual adjustment to the economic environment and seeks to explain the behaviur of the firm and other institutions by observing individual actions within the organization. (Furubotn \& Pejovich, 1972, p. 1138)

In other words, individualist approach available in the mainstream economics, takes decision-making mechanism externally either as an individual or as a company. So the optimisation is handled externally not internally. Consequently, decisions are being taken in a universe called the "market" and players situated within the market are making what was said by this great power. However, the players included in the decision-making mechanisms (individual or company) are able to determine their options and take decisions accordingly.

A central point noted is that property rights do not refer to relations between men and things about, rather, to the sanctioned behavioral relations among men that arise from the existence of things and pertain to their use. Property rights assignments specify the norms of behavior with respect to things that each and every person must observe his interactions with other persons or bear the cost for nonobservance. (Furubotn \& Pejovich, 1972, p. 1139)

It is the interaction between institutions and organizations that shapes the institutional evolution of an economy. If institutions are the rules of the game, organizations and their entrepreneurs are the players. Organizations are made up of groups of individuals bound together by some common purposes to achieve certain objectives. Organizations include political bodies (e.g., political parties, the Senate, a city council, and regulatory bodies), economic bodies (e.g., firms, trade unions, family farms, and cooperatives), social bodies (e.g., churches, clubs, and athletic associations), and educational bodies (e.g., schools, universities, and vocational training centers). (North, 1994, p. 361)

Although NIE does not exactly have the evolutionary feature inherited from OIE, since inter-disciplinary transitivity is high, it may more comfortably focus on human behaviours. However, the problem of rationality could not be fully overcome yet. The prediction that each individual would choose the most economical option for him in a rationalistic manner takes place within NIE, but not as much as in neoclassical economics. Yet this is a breakup from the "institutional human" logic that does not agree OIE's human behaviours as evolutionist and the same in anywhere and any conditions. This breakup is striking (dramatic) from the view of NIE's relationship with neoliberalism. Because the rise of neoliberalism and rise of NIE are almost at the same period of time.

Another concept necessary to be used in order to explicate the relation between NIE and neoliberalism is the "transaction costs" concept. The main axis of this thought of Coase rests on the argument whether markets are effective or not. In other words, if markets operate efficiently (and costless), as neoclassical economics assumes, there would be no need for any company in the market (Şenalp, 2007). Therefore, although the conflict between the logical of NIE and neoliberalism could not be understood at first glance, it is revealed much deeper through the concept of transaction costs. Firstly, the author has already stated that NIE was born with an opposition to OIE. To be more market oriented is a point for NIE to get closer to neoliberalism. Neoliberalism takes economical power primarily from neoclassical economics, and then from currents such as supply sided economy, rational expectations theory, and from the power of market economically. So the market is effective (= costless) in terms of neoliberalism. In other words, the market cannot be efficient. Although NIE 
is an economic stream with complete belief in the market, it has been able to overcome the inefficiency (= market would have a certain cost) through transaction costs concept. So, the existence of companies in the market ensures the market to operate efficiently (costless). In short, the company takes over the work done by the market.

The traditional approach has tended to obscure the nature of the choice that has to be made. The question is commonly thought of as one in which A inflicts harm on B and what has to be decided is: How should we restrain A? But this is wrong. We are dealing with a problem of a reciprocal nature. To avoid the harm to B would inflict harm on A. The real question that has to be decided is: Should A be allowed to harm B or should B be allowed to harm A? The problem is to avoid the more serious harm. (Coase, 1960, p. 2)

However in contrast to the many earlier attempts to overturn or replace neo-classical theory, the new institutional economics builds on, modifies, and extends neo-classical theory to permit it to come to grips and deal with an entire range of issues heretofore beyond its ken. (North, 1993, p. 1)

According to neoclassical economics, acquiring information is costly. NIE minimizes these transaction costs, even makes null. Because transaction costs of maximization of benefit or profit of actors are directly undertaken by the company.

The incomplete information and limited mental capacity by which to process information determines the cost of transacting which underlies the formation of institutions. At issue is not only the rationality postulate but the specific characteristics of transacting that prevent the actors from achieving the joint maximization result of the zero transaction cost model. The costs of transacting arise because information is costly and asymetrically held by the parties to exhange. The costs of measuring the multiple valuable dimensions of the goods or services exchanged or of the performance of agents, and the costs of enforcing agreements determine transaction costs. (North, 1993, p. 2)

Transaction costs can load essentially the cost of an operation to any other part(s) that participate in that operation. Thus the economy runs effectively. In order to load the cost of any operation to any one of the parties, "rational individualism" is essential. Because individuals are able to determine the best options for them may as well maximize their economic interests. Also the "rational individuals" assumption reshaped by NIE with neoclassical economics finds its reflection in transaction costs concept in this way. Although social norms and traditions have been taken into consideration recently, more shares of capital in the shares are received by production factors.

Economic development changes institutions through a number of channels. First, increased wealth due to growth may create higher demands for higher-quality institutions (e.g., demands for political institutions with greater transparency and accountability). Second, greater wealth also makes better institutions more affordable. Institutions are costly to establish and run, and the higher their quality the more "expensive" they become (see below). Third, economic development creates new agents of change, demanding new institutions. In the 18th century, the rising industrial capitalists supported the development of banking against the opposition to it by landlords, while in the late 19th and the early 20th centuries, the growing power of the working class led to the rise of the welfare state and protective labour laws, against the capitalists who thought that those institutions would bring about the end of civilization as they knew it. (Chang, 2011, p. 4)

Transparency and accountability of institutions in terms of economic development are very important. Thus, applications overflowing out of the market, rendering a certain section wealthier but from another aspect compromising the livelihood of the great majority may be at least reduced. Although economic institutions of neoliberalism have no problem in this sense, the problem is the biased side of economic policies. That is why applications during the first period when neoliberalism started to apply conflict with today's practices. While initially the superiority of supply sided economic applications was available, NIE has been put into operation 
both for more efficient applications of policies and for increasing effectiveness of institutions. Therefore, this newly created perspective has launched its literature and put such applications into operation including "property rights", "transaction costs", and so on that have not already been focused.

So, for example, the (Anglo-American) common-law legal system is seen as more encouraging of enterprise, and thus economic growth, than the (Continental, especially French) civil-law system, because it provides better protection of investors and creditors while minimizing state regulation. For another example, it is argued that a shareholder-oriented (once again, essentially Anglo-American) corporate governance system promotes investment and thus growth by giving assurance to investors that they will not be ripped off by other stakeholders in the company they invest in - the managers, the workers, and the suppliers, who will get the same fixed compensation regardless of the profit performance of the company and thus have no incentive to maximize profit. However, the relationship between institutions and economic development is far more complex than that. (Chang, 2011, p. 5)

The application process is the "neoliberalism" corresponding to a system based on an anachronistic production model transformed into a component of the "race toward the bottom" in line with "competitiveness" and "export concepts" that have been fetishized under the imposition of "the market solves everything" (Yeldan, 2015).

If one can give a summary about the relation between NIE and neoliberalism, it can be briefly possible to say that, there is a great tie between them. Neoliberalism far differs from liberalism in the application. Some economics theories have emerged to help neoliberalism by the mediation of economics mind. NIE is one of them. It has launched by early in 1990s, rejecting its relationship with OIE. NIE has three important concepts: "bounded rationality", "transaction costs", and "property rights". Last two notions seem to give an effect like that there is an enforcement support to neoliberalism where its hard core neoclassical economics is inefficient. However, the first one is a really important notion providing for rational mind's lack.

\section{Conclusions}

The very first origins of neoliberalism can be traced back to 18th century. However, neoliberalism has defined itself in a totally different way where its origin can be called as if it was a "traitor child". Because, neoliberalism has not had a single description to be given. Neoliberalism is handled by a way of thought. Albeit this thought denies that it has a structuralist tie, actually it steps many countries' structure out which is affected by the world for the author's opinion. This structure affects everything from economics to politics, culture, and sociological structure. But, economics has higher importance from rest. This is because, any structural change made in economics affects the rest of human life.

The main basis is that the origin of neoliberalism in economics lies down to neoclassical economics. Neoliberalism has been supported by monetarism, supply-side economics, etc. which are arised from wild neoclassical economics. Neoliberalism has never been a process which is like a skate sliding down from a troubleness and slippery ground. It has witnessed many rugged steps. When a thought which has supported itself in the economics area, there had been substituted with a new thought arised from neoclassical economics. The relationship between neoliberalism and NIE has started at this point. Starting rapidly from early beginning of the 1990s, NIE is the new favorite one for neoliberalism. The most important reason of this situation is "the institution" notion which is the common one of NIE and OIE. Nevertheless, NIE is interdiciplinary which is releated with the areas, such as economics to law, antropology, sociology, etc. This interdiciplinary way gives self a chance to look at economics multi-functionally, however, the close relationship between neoclassical 
economics has hindered it from the psychology of "focusing the market". The fetishism of "the market solves everything" has actually caused to see or to be ignored by real problems in the market.

In addition to this market adoration, three notions which have been gained by NIE to the liteature have been recruited the relationship between neoliberalism and NIE. These are "transaction costs", "property rights", and "bounded rationality".

Transaction costs notion tries to find the answer of that if there is a market which is powerful so as a firm does. It gives an answer, firm undertakes every transaction costs (= risks) in every transaction. So, for neoliberalism, transaction costs put the firm's, which is the most powerful side of the market, adequacy, and necessity forward. Property rights have internalized the optimization problem which neoclassical economics accepts as external. Induviduals or firms are the owners of the prosperities in the market game who decide their own decisions for this. At the first sight, it seems as if every side participates in eqaul conditions, virtually there is an unfair situation. Because, it is not possible to participate every decision making process in the market, each individual or firm cannot join these decision making processes in equal conditions. This situation makes neoliberalism only one-way look. Bounded rationality notion is a much more logical notion to rational individual. The induviduals who are not able to see what happens in the real world, people make their decisions in ambiguity or risky conditions. This notion is an important one, that is because it has a power to reduce the ambiguity problem much less. It can be said that it is one of the most important notions which can give a wide range look to neoliberalism.

Essentially, neoliberalism is related to who does receive how much share from production factors. Sure, capital class has a weigh in the economics it receives much more share from production factors. So, it can be said that neoliberalism is the way to find a path how capital class receives much more share. Neoliberalism is irrelevant to liberalism. Because liberalism endures to freedom of induviduals, yet neoliberalism leans to absolute market freedom. Because, "neoliberal strategy and capital class lay all the cost on worker class by executing policies that regulate the redistribution of the surplus value on its own interest to accelerate the capital accumulation" (Altiok, 2008, p. 1304).

Shortly, that is because neoliberalism paradigm has its multi-functional structure, it helps to produce different kinds of economics liteatures. These liteatures arise from the very core of neoclassical economics. All these liteatures try to help the applications of economics. NIE is one of these liteatures. NIE seems to have very close relationship with neoliberalism by the mediation of its own production notions.

\section{References}

Altıok, M. (2008). Washington consensus. In F. Başkaya and A. Ördek (Eds.), Ekonomik kurumlar ve kavramlar sözlüğü. Eleştirel bir giriş (The dictionary of ınstitutions and notions of economics. An critical introduction) (pp. 1297-1306). Ankara: Maki Basın Yayın.

Arrow, K. A. (1994). Methodological individualism and social knowledge. American Economic Review, 84(2), 1-9.

Bholat, D. (2010). Hayek's "great society": On civilization and its savages. Journal of Political Ideologies, 15(2), 175-188.

Chang, H. J. (2006). Understanding the relationship between institutions and economic development (Discussion paper No. 2006/05, United Nation University, Japan).

Chang, H. J. (2011). Institutions and economic development: Theory, policy and history. Journal of Institutional Economics, 7(4), 473-498.

Clarke, S. (2004). The neoliberal theory of society. In A. Saad-Filho and D. Johnston (Eds.), Neoliberalism: A critical reader (pp. 50-59). London: Pluto Press.

Coase, R. (1998). The new institutional economics. AEA Papers and Proceedings, 88(2), 72-74. 
Coase, R. H. (1960). The problem of social cost. The Journal of Law of Economics, 3, 1-44.

Duménil, G., \& Lévy, D. (2004). The neoliberal (counter-) revolution. In A. Saad-Filho and D. Johnston (Eds.), Neoliberalism: A critical reader (pp. 9-19). London: Pluto Press.

Eğilmez, M. (2015). Sağ, sol, kapitalizm, sosyalizm, demokrasi ve eğitim (Right, left, capitalism, socialism, democracy and education). Retrieved from http://www.mahfiegilmez.com/2015/05/sag-sol-kapitalizm-sosyalizm-demokrasi.html

Eres, B. (2008). Liberalism, Neoliberalizm (Liberalism, Neoliberalism). In F. Başkaya and A. Ördek (Eds.), Ekonomik Kurumlar ve Kavramlar Sözlüğ̈̈. Eleştirel Bir Giriş (The dictionary of ınstitutions and notions of economics. An critical introduction) (pp. 755-770). Ankara: Maki Basın Yayın.

Frey, B., \& Eichenberger, R. (1992). Economics and economists: A European perspective. AEA Papers and Proceedings, 82(2), 216-220.

Friedman, M., \& Schwartz, A. J. (1963). A monetary history of the United States 1867-1960. Princeton, New Jersey: Princeton University Press.

Furubotn, E. G., \& Pejovich, S. (1972). Property rights and economic theory: A survey of recent literature. Journal of Economic Literature, 10(4), 1137-1162.

Hart-Landsberg, M. (2008). Neo-Liberalizm: Mitler ve Gerçeklik (Neoliberalism: Myths and truth). Istanbul: Kalkedon Yayınları.

Hayek, F. A. (1945). The use of knowledge in society. The American Economic Review, 35(4), 519-530.

Heiner, R. (1983). The origin of predictable behavior. American Economic Review, 4(73), 560-595.

Hodgson, G. M. (1998). The approach of institutional economics. Journal of Economic Literature, 36, 166-192.

Hodgson, G. M. (2000). What is the essence of institutional economics? Journal of Economics Issues, 34(2), 317-329.

Hodgson, G. M. (2003). John R. Commons and the foundation of institutional economics. Journal of Economic Issues, 37(3), 547-576.

Kapp, K. W. (1968). In defence of institutional economics. Sweden Journal of Economics, 70(1), 1-18.

Langlois, R. N. (1989). What was wrong with the old institutional economics (and what is still wrong with new new)? Reivew of Political Economy, 1(3), 270-298.

Lapavitsas, C. (2004). Mainstream economics in the neoliberal era. In A. Saad-Filho and D. Johnston (Eds.), Neoliberalism: A critical reader (pp. 30-49). London: Pluto Press.

Munck, R. (2004). Neoliberalism and politics, and the politics of neoliberalism. In A. Saad-Filho and D. Johnston (Eds.), Neoliberalism: A critical reader (pp. 60-69). London: Pluto Press.

North, D. (1993). The new institutional economics and development. Retrieved from http://www2.econ.iastate.edu/tesfatsi/NewInstE.North.pdf

North, D. (1994). Economic performance through time. The American Economic Review, 84(3), 359-368.

Palermo, G. (2000). Economic power and the firm in new institutional economics: Two conflicting problems. Journal of Economic Issues, 34(3), 573-601.

Palley, T. I. (2004). From Keynesianism to neoliberalism: Shifting paradigms in econimics. In A. Saad-Filho and D. Johnston (Eds.), Neoliberalism: A critical reader (pp. 20-29). London: Pluto Press.

Posner, R. A. (1987). The law and economics movement. AEA Papers and Proceedings, 77(2), 1-13.

Posner, R. A. (1993). The new institutional economics meets law and economics. Journal of Institutional and Theoretical Economics, 149(1), 73-87.

Radice, H. (2004). Neoliberal globalisation: Imperialism without empires? In A. Saad-Filho and D. Johnston (Eds.), Neoliberalism: A critical reader (pp. 91-98). London: Pluto Press.

Rodrik, D. (2004). Getting institutions right, mimeo (Kennedy School of Government, Harvard University).

Rutherford, M. (2001). Institutional economics: Then and now. Journal of Economic Perspectives, 15(3), 173-194.

Saad-Filho, A. (2004). From Washington to post-Washington consensus: Neoliberal agendas for economic development. In A. Saad-Filho and D. Johnston (Eds.), Neoliberalism: A critical reader (pp. 113-119). London: Pluto Press.

Schmidt, I. (2008). Krizleri Kiyaslamak: 1930'lar, 1970'ler ve Bugün (Comparing crisis: 1930s, 1970s and today). Istanbul: Kalkedon Yayınları.

Shaikh, A. (2004). The economic mythology of neoliberalism. In A. Saad-Filho and D. Johnston (Eds.), Neoliberalism: A critical reader (pp. 41-49). London: Pluto Press.

Simon, H. (1955). A behavioral model of rational choice. Quarterly Journal of Economics, 69, 99-118.

Steger, M. B., \& Roy, R. K. (2010). What's "neo" about liberalism. In M. B. Steger and R. K. Roy (Eds.), Neoliberalism: A key short introduction (pp. 1-49). London: Oxford University Press. 
Stein, H. (2008). Beyond the world bank agenda-An institutional approach to development. Chicago: University of Chicago Press.

Şenalp, M. G. (2007). Dünden Bugüne Kurumsal İktisat (Institutional economics from past and today). In E. Özveren (Ed.), Kurumsal iktisat (Institutional economics) (pp. 45-92). Ankara: İmge Kitabevi.

Thorsen Einar, D., \& Lie, A. (2007). What is neoliberalism? In D. H. Claes, A. Lie, and P. K. Mydske (Eds.), Nyliberalisme-ideer org politisk virkelighet (pp. 2-21). Norway: Universitetsforlaget.

Voigt, S., \& Engerer, H. (1999). Institutions and transition: Possible policy 1mplications of the new institutional economics (Social science research network working paper).

Williamson, O. E. (1975). Markets and hierarchies: Analysis and anti-trust implications. A study in the economics of internal organization. New York: The Free Press.

Williamson, O. E. (1998a). The institutions of governance. AEA Papers and Proceedings, 88(2), 75-79.

Williamson, O. E. (1998b). Transaction cost economics: How it works; where it is headed. De Economist, 146(1), 23-58.

Yeldan, E. (2015). Diren Metal (Occupy metal). Cumhuriyet. Retrieved from https://yeldane.files.wordpress.com/2014/09/yeldan508_27may15.pdf 